\title{
Die freie Rechtswahl im Kollisionsrecht der außervertraglichen Schuldverhältnisse
}

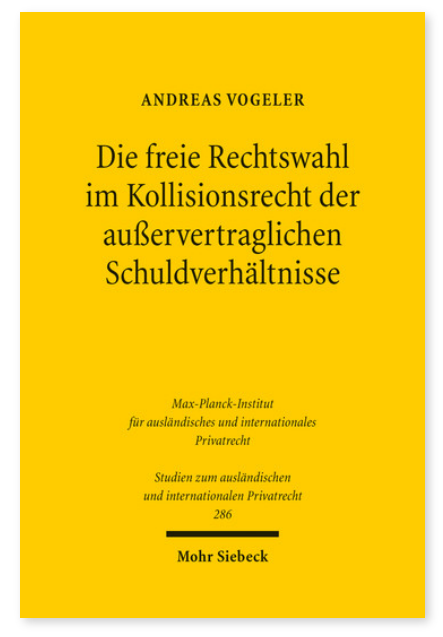

2013. XXVI, 470 Seiten. StudIPR 286

ISBN 978-3-16-152619-0

DOI 10.1628/978-3-16-152619-0

eBook PDF 109,00€

ISBN 978-3-16-152397-7

fadengeheftete Broschur 109,00€
Mit der Kodifikation des Art. 14 Rom II-VO hat der europäische Gesetzgeber die Voraussetzungen für die Ausübung der Parteiautonomie im Bereich der außervertraglichen Schuldverhältnisse europarechtlich harmonisiert. Mit ihr sollen die Grundlagen geschaffen werden, um die Prozessführung im In- und Ausland bei grenzüberschreitenden Streitigkeiten zu vereinfachen. Die Parteien können danach grundsätzlich das Sachrecht frei wählen, welches über ein bestehendes oder künftiges außervertragliches Schuldverhältnis entscheiden soll. Art. 14 Rom II-VO erhält damit neue Bedeutung für die Rechtspraxis. Andreas Vogeler untersucht, unter welchen Voraussetzungen eine Rechtswahlvereinbarung geschlossen werden kann und zeigt weiteren gesetzgeberischen Handlungsbedarf auf.

Andreas Vogeler Geboren 1985; Studium der Rechtswissenschaft in Göttingen und Genf; 2012 Promotion; derzeit Rechtsreferendar am Kammergericht Berlin.

Jetzt bestellen:

https://mohrsiebeck.com/buch/die-freie-rechtswahl-im-kollisionsrecht-der-ausservertraglichen-schuldverhaeltnisse9783161526190?no_cache=1

order@mohrsiebeck.com

Telefon: +49 (0)7071-923-17

Telefax: +49 (0)7071-51104 